\title{
PTPRG wt Allele
}

National Cancer Institute

\section{Source}

National Cancer Institute. PTPRG wt Allele. NCI Thesaurus. Code C49535.

Human PTPRG wild-type allele is located within 3p21-p14 and is approximately $732 \mathrm{~kb}$ in length. This allele, which encodes receptor-type tyrosine-protein phosphatase gamma protein, plays a role in the dephosphorylation of protein-tyrosine phosphates. 